\title{
Estimation of absolute water content in Spitsbergen glaciers from radar sounding data ${ }^{1}$
}

\author{
Yuri Ya. Macheret \& Andrey F. Glazovsky
}

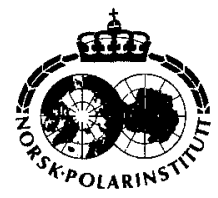

Field data available on radio-wave velocities and power reflection coefficients from the cold/temperate ice boundary have been used to estimate the absolute water content and its variations in the temperate ice of two-layered glaciers on Spitsbergen. The data have been interpreted with certain assumptions concerning radio-wave propagation and reflection models. The study shows that in cold periods, the average total water content in the upper part of the temperate ice varies in different glaciers from 2.8 to $9.1 \%$. Macro inclusions might contain the major part of the total water volume. Within one glacier, the spatial variability of water content in the upper part of the temperate ice is 1.7$11.9 \%$. Seasonal variation of the total water content in the temperate layer reaches $2.3 \%$ (from $0.1 \%$ in spring to $2.4 \%$ in summer). Water content distribution with depth can vary: either it has a maximum up to $5.0 \%$ (even in spring) in the upper 30-60 $\mathrm{m}$ of the temperate ice. then decreases downward: or it is more uniform. Water content in the upper part of temperate ice and bedrock reflection coefficients reveal a rather close relation with surficial melting rate at the ELA and with ice facies zones. Water storage in the temperate layer is enough to feed englacial run-off during the whole cold period.

Y. Ya. Macheret \& A. F. Glazorsky, Institute of Geography, Russian Academy of Sciences, Staromonetny per. 29. 109017 Moscow, Russia.

Absolute water content in glaciers is an important and little known parameter which in many ways defines their hydrothermal state. regime and dynamics. For its determination in situ in temperate and subpolar glaciers, the data on radio-wave velocities (RWVs) obtained by the wide-angle reflection method, radar logging of boreholes and radio-echo sounding (RES) in the vicinity of boreholes and from hyperbolic reflections from englacial reflectors, as well as formulae describing the dependence of the dielectric permittivity of wet ice on water content are applicable (Macheret. Moskalevsky et al. 1993; Frolov \& Macheret 1998; Moore et al. 1999). RES data on power

\footnotetext{
This paper was originally submitted in connection with the International Symposium on Polar Aspects of Global Chatrge. Tromsø, Norway. 24-28 August 1998. - The Editor.
}

reflection coefficients (PRCs) from the cold/ temperate ice boundary can also be used to estimate the absolute water content in the temperate ice of polythermal (two-layered) glaciers near to the boundary (Macheret \& Zhuravley 1985: Bamber 1987b). RES data on backscattered power from water inclusions can also be used to estimate the relative water content in temperate ice (Hamran et al. 1996). The absolute data obtained by the above-mentioned methods can be applied to calibrate relative estimations. Thus the set of radar techniques might be applied to estimate both the water content in two-layered glaciers at fixed sites along the radar wave-paths and its variations along RES profiles.

Our prime interests here are the spatial and seasonal variations of absolute water content in twolayered glaciers on Spitsbergen, where more than 80 
such glaciers were studied using data from airborne RES at frequencies of 440,620 and $60 \mathrm{MHz}$; many of these have winter englacial run-off and are surgetype glaciers (Glazovsky, Krass et al. 1998). A specific indicator of two-layered glaciers is an internal reflecting horizon (IRH) clearly visible on many RES records as a continuous track (Bamber 1987b; Macheret, Glazovsky etal. 1992). The IRH is located close to the depth where direct temperature measurements in boreholes indicate that the ice is at pressure-melting point (Macheret, Zagorodnov et al. 1985; Björnsson et al. 1996; Ødegård et al. 1997).

This paper considers the spatial and seasonal variations of absolute water content in the temperate ice of two-layered Spitsbergen glaciers and their relation to glacioclimatic conditions and internal structure of glaciers. The analysis is based on data on PRCs from IRH (Bamber 1987a, 1989) and RWVs (Macheret, Zhuravlev et al. 1980; Macheret, Vasilenko et al. 1984; Macheret, Moskalevsky et al. 1993), measured in spring and summer periods of 1977-1989, that together cover almost a quarter of the two-layered glaciers known on Spitsbergen (Fig. 1).

\section{Estimation of absolute water content and relevant parameters}

Since dielectric losses in ice and fresh water are small (tangent of dielectric losses $\tan \delta<<1$ ), the real part of dielectric permittivity $\varepsilon^{\prime}$ of dry and wet ice relates to radio-wave velocities $V$ by simple equations:

$$
\varepsilon_{\mathrm{d}}^{\prime}=\left(\mathrm{c} / V_{\mathrm{d}}\right)^{2}, \varepsilon_{\mathrm{s}}^{\prime}=\left(\mathrm{c} / V_{\mathrm{s}}\right)^{2}
$$

where $c$ is light velocity in vacuum, indexes $d$ and $s$ denote dry and wet ice, respectively.

As is known (e.g. Bamber 1989), the PRC from a boundary of two semi-infinite ice layers depends on their dielectric permittivity, boundary roughness, and volume content and size of air and water inclusions in ice. Two latter parameters usually are poorly known, therefore for the estimation of power reflection coefficient $R(\mathrm{~dB})$ we use a simple model of radio-wave reflection from a plane dry/wet ice boundary. In this case, $R$ is determined as

$$
R=20 \log _{10}\left[\left(\sqrt{ } \varepsilon_{\mathrm{S}}^{\prime}-\sqrt{ } \varepsilon^{\prime}{ }_{\mathrm{d}}\right) /\left(\sqrt{ }{\varepsilon^{\prime}}_{\mathrm{S}}+\sqrt{ } \varepsilon_{\mathrm{d}}^{\prime}\right)\right]
$$

from where

$$
\varepsilon_{\mathrm{s}}^{\prime}=\varepsilon_{\mathrm{d}}^{\prime}\left[\left(1+10^{0.05 \mathrm{R}}\right) /\left(1-10^{0.05 R}\right)\right]^{2} .
$$

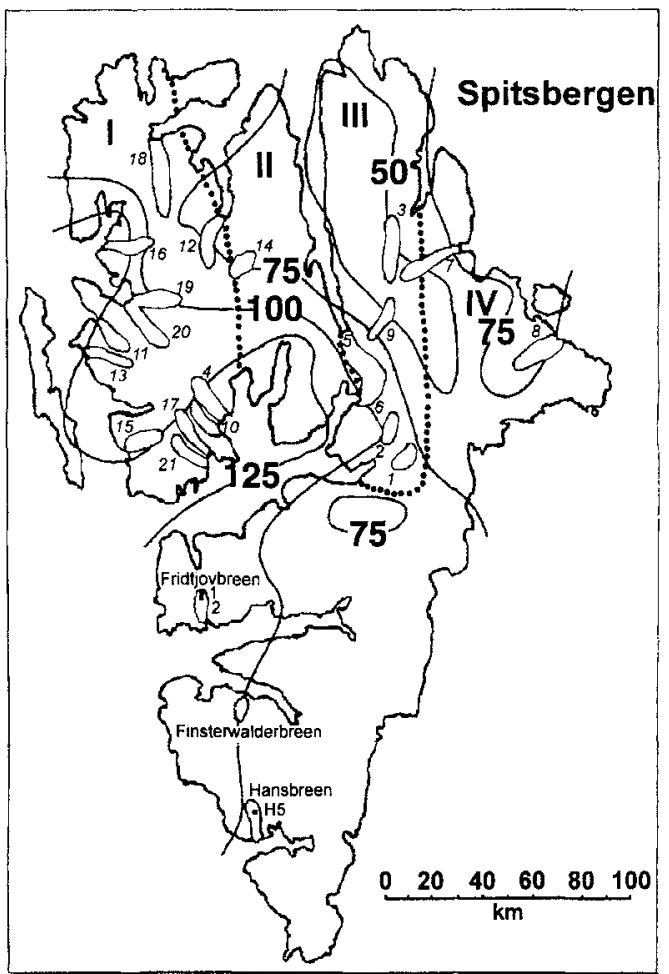

Fig. 1. Two-layered glaciers in northern Spitsbergen where data on power reflection coefficients from internal reflecting horizon (IRH) and radio-wave velocities were obtained and used to estimate absolute water content in temperate ice (Tables 1, 2). The glaciers are shown with their numbers (italic type) as given in Table 2. On Fridtjovbreen and Hansbreen the sites of radiowave velocity measurements (boreholes 1 and 2, H5) are indicated. Contour lines show surficial melting rate $\left(\mathrm{g} \mathrm{cm}^{-2}\right)$ at equilibrium line altitude (ELA) (adapted, with permission, from Koryakin et al. 1985). The regions with predominan ice facies zones are divided by dotted lines with following indexes: I are cold firn and warm firn zones; II are superimposed ice; III are firn ice and cold firn zones; IV are cold firn and warm firn zones (adapted, with permission, from Treshnikov 1985).

Note that values of $\varepsilon_{d}^{\prime}$ and $\varepsilon_{s}^{\prime}$ in equation (2) are the dielectric permittivity of dry and wet glacier ice, respectively, at their boundary.

Wide-angle reflection measurements and RES data near borehole allow estimates of the average radio-wave velocities $V$ in a glacier and $V_{\mathrm{d}}$ in its cold layer, as well as glacier thickness $h$ and cold layer thickness $h_{\mathrm{d}}$. Assuming that the effect of radio-wave refraction at the cold/temperate ice boundary is small (Babenko \& Macheret 1996), the RWV in temperate ice is equal to

$$
V_{\mathrm{s}}=\left(h-h_{\mathrm{d}}\right) V_{\mathrm{d}} V /\left(\dot{h} V_{\mathrm{d}}-h_{\mathrm{d}} V\right) \text {. }
$$

If there is an additional reflecting boundary in 
temperate ice, the average RWV in its upper part $V_{\mathrm{s} 1}$ and lower part $V_{\mathrm{s} 2}$ with ice thickness $h_{\mathrm{s} 1}$ and $h_{\mathrm{s} 2}$, respectively, are calculated from equations

$$
\begin{gathered}
V_{\mathrm{s} 1}=\left(h_{\mathrm{ds}}-h_{\mathrm{d}}\right) V_{\mathrm{ds}} V_{\mathrm{d}} /\left(h_{\mathrm{ds}} V_{\mathrm{d}}-h_{\mathrm{d}} V_{\mathrm{ds}}\right),(3 \\
V_{\mathrm{s} 2}=\left(h-h_{\mathrm{ds}}\right) V_{\mathrm{ds}} V /\left(h V_{\mathrm{ds}}-h_{\mathrm{ds}} V\right)
\end{gathered}
$$

where $V_{\mathrm{ds}}$ is measured average RWV in ice sequence that includes cold ice and the upper part of temperate ice with total thickness $h_{\mathrm{ds}}$. In all cases it is assumed that the IRH and the cold/ temperate ice boundary are at the same depth. From data on radar logging of boreholes, the average RWVs both in cold and temperate ice and in their specific layers have been determined (Kotlyakov \& Macheret 1987).

Analysis of experimental data on the dielectric permittivity of wet snow at density less than 0.5 $0.6 \mathrm{Mg} \mathrm{m}^{-3}$ (Frolov \& Macheret 1998) shows that the absolute water content, $W$, in wet ice at densities more than $0.8 \mathrm{Mg} \mathrm{m}^{-3}$ can be estimated using the formula of Looyenga (1965) for two- and three-component dielectric mixtures with spherical air and air/water inclusions, respectively. The Looyenga's formula is a particular case of an exponential model describing the dielectric permittivity, $\varepsilon_{m}^{\prime}$ of mixture as a function of dielectric permittivities, $\varepsilon_{\mathrm{k}}^{\prime}$ of $k^{\text {th }}$ components with a volume portion $f_{\mathrm{k}}$ (Sihvola et al. 1985)

$$
\varepsilon_{\mathrm{m}}^{\mathrm{a}}=\Sigma f_{\mathrm{k}} \varepsilon_{\mathrm{k}}^{\mathrm{a}}
$$

where $a=1 / 3$. For two-component dielectric mixture of ice and water, in which all the cavities are water-filled, the equation (4) is transformed to

$$
\varepsilon_{\mathrm{s}}^{\prime}=\left[\left(\varepsilon_{\mathrm{i}}^{\prime 1 / 3}+W\left(\varepsilon_{\mathrm{w}}^{\prime}{ }^{1 / 3}-\varepsilon_{\mathrm{i}}^{\prime 1 / 3}\right)\right]^{3}\right.
$$

where $\varepsilon_{s}^{\prime}, \varepsilon_{i}^{\prime}$ and $\varepsilon^{\prime}{ }_{w}$ is dielectric permittivity of wet glacier ice, solid ice and water, respectively. The value $W$ is total water content dispersed as micro and macro inclusions in ice. Veins, lenses and films at ice grains' boundaries with typical dimensions less than $1 \mathrm{~mm}$ are referred here as micro inclusions or pores. Cavities and channels of $>1 \mathrm{~mm}$ in size are named here as macro inclusions.

From equation (5) follows that the total water content in temperate ice is equal to

$$
W=\left(\varepsilon_{5}^{\prime 1 / 3}-\varepsilon_{i}^{\prime 1 / 3}\right) /\left(\varepsilon_{\mathrm{w}}^{\prime 1 / 3}-\varepsilon_{\mathrm{i}}^{\prime 1 / 3}\right) .
$$

For the three-component system. representing mixture of ice with water and air inclusions, the dielectric permittivity, $\varepsilon_{\mathrm{s}}^{\prime}$ is estimated from equation (4) as

$$
\varepsilon_{\mathrm{s}}^{\prime}=\left[\varepsilon_{\mathrm{i}}^{\prime 1 / 3}(1-P)+W{\varepsilon_{\mathrm{w}}^{\prime}}^{1 / 3}+P-W\right]^{3}
$$

where $P$ is the total fractional water and air content, or total "porosity" of temperate ice.

Cold glacier ice is a two-component dielectric mixture of ice and air. Its permittivity, $\varepsilon_{d}^{\prime}$ in equations (2) and (5) can also be estimated from Looyenga's formula (4) as

$$
\varepsilon_{\mathrm{d}}^{\prime}=\left[f_{\mathrm{i}}^{1 / 3}\left({\varepsilon_{\mathrm{i}}}^{1 / 3}-1\right)+1\right]^{3}
$$

where $f_{\mathrm{i}}=\rho_{\mathrm{d}} / \rho_{\mathrm{i}}, \rho_{\mathrm{d}}$ is the density of cold glacier ice, and $\rho_{\mathrm{i}}$ is density of solid ice $\left(\rho_{\mathrm{i}}=0.917 \mathrm{Mg} \mathrm{m}^{-3}\right)$.

Equation (1) and (8) can be also used to estimate the average density, $\rho_{\mathrm{a}}$ of cold glacier ice from the measured velocity $V_{\mathrm{d}}$

$$
\rho_{\mathrm{a}}=\rho_{\mathrm{i}}\left\{\left[\left(c / V_{\mathrm{i}}\right)^{2 / 3}-1\right] /\left[\left(\mathrm{c} / V_{\mathrm{i}}\right)^{2 / 3}-1\right]\right\} .
$$

Accordingly, the average "voidness" is $p_{\mathrm{a}}=1-$ $\rho_{\mathrm{a}} / \rho_{\mathrm{i}}$, which accounts macro and micro air inclusions in cold glacier ice.

On the other hand, the integral average density, $\rho_{\mathrm{o}}$ of cold glacier ice, estimated from ice core data. corresponds to the micro air inclusions only and its average porosity is

$$
\Delta \mathrm{p}=p_{\mathrm{a}}-p_{\mathrm{o}}
$$

where $p_{\mathrm{o}}=1-\rho_{\mathrm{o}} / \rho_{\mathrm{i}}$.

It is known (Evans 1965; Fujita et al. 1993) that in the frequency range from $1 \mathrm{MHz}$ to $10000 \mathrm{MHz}$, the dielectric permittivity $\varepsilon_{\mathrm{i}}^{\prime}$ of solid ice weakly depends on frequency, ice temperature, anisotropy and small concentration of soluble chemical impurities. Generalization of experimental data by Gough (1972), Mätzler \& Wegmüller (1987) and others on the temperature dependence of $\varepsilon_{i}^{\prime}$ has shown (Frolov \& Macheret 1998) that $\varepsilon_{i}^{\prime}=3.19 \pm 0.04$ at a temperature of $0^{\circ} \mathrm{C}$, which corresponds to velocity in solid ice of $V_{\mathrm{i}}=168 \pm 1 \mathrm{~m} \mathrm{ss}^{-1}$. In the RES frequency range $(1-1000 \mathrm{MHz})$, the dielectric permittivity of water $\varepsilon^{\prime}$ is constant and equal to 86 (Smith \& Evans 1972).

In further calculations we suggest that $\varepsilon_{i}^{\prime}=3.19$ and $\varepsilon^{\prime}{ }_{\mathrm{w}}=86$ at the melting point. The values of ice density at base of the cold ice, $\rho_{\mathrm{d}}=0.912 \mathrm{Mg} \mathrm{m}^{-3}$, and the average integral density of cold ice, $\rho_{\mathrm{o}}=0.904 \mathrm{Mg} \mathrm{m}^{-3}$ (porosity $p_{\mathrm{o}}=1.4 \%$ ), used in equations (2) and (10), respectively, are taken from density measurements on an ice core from borehole 2 on Fridtjovbreen (Macheret, Zagorodnov et al. 1985).

The dependencies $W=\mathrm{f}\left(V_{\mathrm{s}}\right), \rho_{\mathrm{a}}=\mathrm{f}\left(V_{\mathrm{d}}\right)$ and 


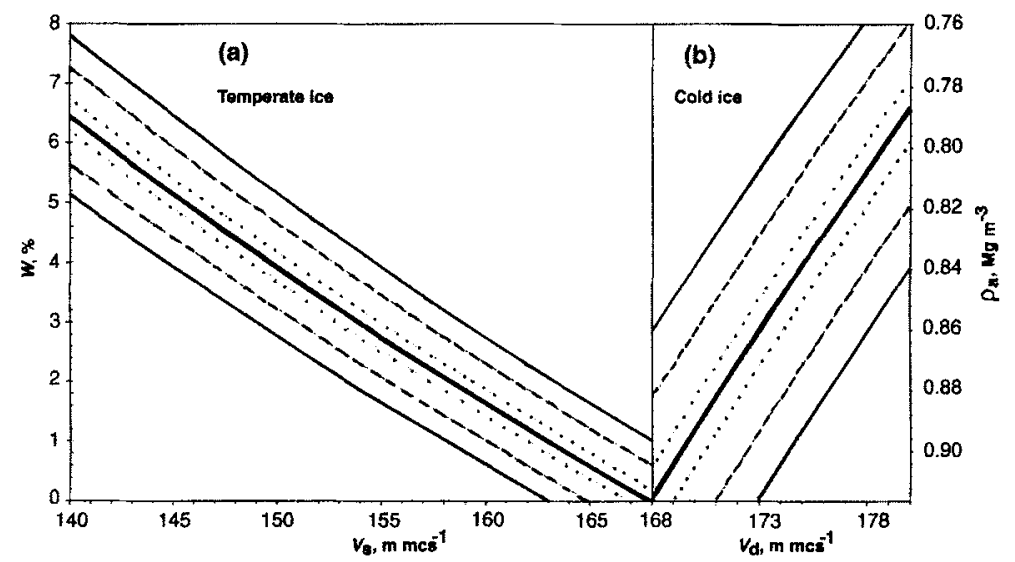

Fig. 2. Relationships of radiowave velocity in (a) temperate ice $V_{\mathrm{s}}$ with water content $W$; and (b) radio-wave velocity in cold ice $V_{\mathrm{d}}$ with ice density $\rho_{\mathrm{d}}$ Thin lines show the error bands in calculation of $W$ and $\rho_{\mathrm{d}}$ resulting from the uncertainty of $V \pm 1 \mathrm{~m} \mu \mathrm{s}^{-1}$ (dotted line), $\pm 3 \mathrm{~m} \mathrm{ss}^{-1}$ (dashed line) $\pm 5 \mathrm{~m} \mathrm{\mu s}^{-1}$ (solid line). respectively.
$W=\mathrm{f}(R)$ as well as the sensitivity of $W$ and $\rho$. estimations to the accuracy of RWV and PRC data are shown in Figs. 2 and 3. Errors in estimations of $W$ and $\rho$ a (by equations 1,6 and 9) are $\pm 0.27 \%$ and $\pm 0.01 \mathrm{Mg} \mathrm{m}^{-3}$, respectively, if the errors in measurements of $V_{\mathrm{s}}$ and $V_{\mathrm{d}}$ are $\pm 1 \mathrm{~m} \mu \mathrm{s}^{-1}$. Uncertainty increases by a magnitude of two or three if the measurement errors increase up to $\pm 3-$ $5 \mathrm{~m} \mathrm{ss}^{-1}$. Errors in calculations of $W$ (by equations 2 and 6) are $\pm 0.15-1.66 \%$, if error in measurements of $R$ is $\pm 1 \mathrm{~dB}$. They increase up to $\pm 0.32-$ $3.64 \%$ when $R$ error is $\pm 2 \mathrm{~dB}$, and up to \pm 0.43 $5.60 \%$ at $R$ error $\pm 3 \mathrm{~dB}$. As seen in Fig. 3, the uncertainty of water content estimations increases strongly in the range of high $R$ values. On the other hand, the sensitivity of calculations of $W$ from $R$

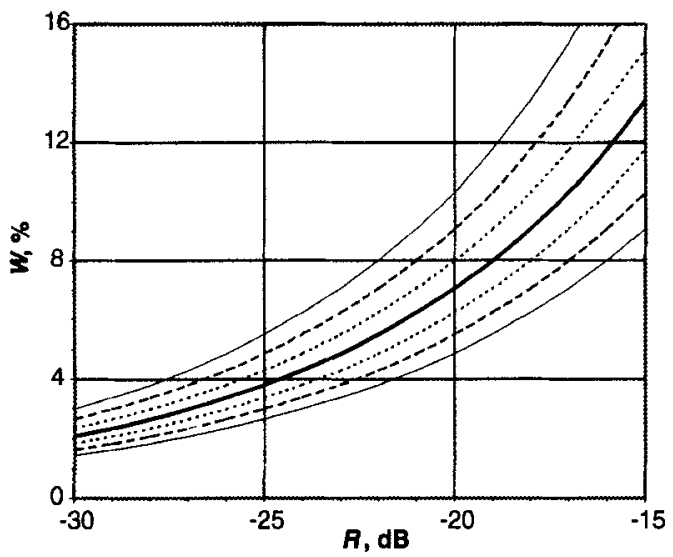

Fig. 3. Relationship of power reflection coefficient $R$ and absolute water content $W$. Thin lines show the error bands in calculation of $W$ resulting from the uncertainty of $R \pm 1 \mathrm{~dB}$ (dotted line), $\pm 2 \mathrm{~dB}$ (dashed line), $\pm 3 \mathrm{~dB}$ (solid line). values to the density $\rho_{\mathrm{d}}$ of cold glacier ice, which is used in equations (2), (6) and (8), does not exceed $0.4 \%$ over the density range from 0.900 to $0.917 \mathrm{Mg} \mathrm{m}^{-3}$.

The actual errors in $V_{\mathrm{d}}$ and $V_{\mathrm{s}}$ are $\pm 2-6 \mathrm{~m} \mu \mathrm{s}^{-1}$ and $\pm 3.5-8.5 \mathrm{~m} \mathrm{ss}^{-1}$, respectively, depending on many factors (Macheret, Moskalevsky et al. 1993), while the errors in $R$ are close to $\pm 2-3 \mathrm{~dB}$ depending mainly on estimated dielectric absorption, scattering in cold ice and calibration errors (Bamber 1989). So both methods have comparable accuracy in absolute water content estimations by equations (2)-(6) and (8) if the errors in $R$ estimations are close to $\pm 2 \mathrm{~dB}$ in $R$ range from -30 to $-22 \mathrm{~dB}$. Note again that this conclusion is valid for a plane cold/temperate ice boundary only.

\section{Radar sounding data}

For estimation of spatial and seasonal variations in absolute water content in temperate ice of twolayered glaciers on Spitsbergen the data available on PRCs from IRH and RWVs were used (Table 1).

Average power reflection coefficients $R_{\mathrm{a}}$ from IRH obtained from $60 \mathrm{MHz}$ airborne radio-echo sounding data collected on 21 glaciers in northern Spitsbergen in May 1983 (Bamber 1989) are given in Table 2 . The values of $R_{\mathrm{a}}$ have been found by averaging of PRCs calculated from digitized individual wave forms collected at intervals of about $120 \mathrm{~m}$ along a flight line using the basic radar equation and measured power of reflected signals from the IRH. Spatial variations in individual power reflection coefficients $R$ from 
Table 1. Datia of airborne and ground-based radio-echo sounding used for the estimation of absolute water content in two-layered glaciers on Spitsbergen and its spatial and seasonal variations. $R$ is power reflection coefficient from internal reflecting horizon, $V$ is radio-wave velocity.

\begin{tabular}{|c|c|c|c|c|c|}
\hline Method of measurements & $\begin{array}{l}\text { Radar } \\
\text { frequency. } \\
\text { MHz }\end{array}$ & $\begin{array}{l}\text { Measured } \\
\text { parameter }\end{array}$ & $\begin{array}{l}\text { Month/ year of } \\
\text { measurements }\end{array}$ & $\begin{array}{l}\text { Glacier, region } \\
\text { (Fig. L) }\end{array}$ & Sources \\
\hline $\begin{array}{l}\text { Airborne radio-echo } \\
\text { sounding (RES) }\end{array}$ & 60 & $R$ & Maly 1983 & $\begin{array}{l}21 \text { glaciers } \\
\text { (Table 2) }\end{array}$ & Bamber $1987 \mathrm{a}, \mathrm{b}, 1989$ \\
\hline $\begin{array}{l}\text { Ground-based RES in the } \\
\text { vicinity of a borehole }\end{array}$ & 620 & $v$ & July 1977 & $\begin{array}{c}\text { Fridtjovbreen. } \\
\text { borehole } 1\end{array}$ & $\begin{array}{l}\text { Macheret, Zhuravlev et al. } \\
1980\end{array}$ \\
\hline $\begin{array}{l}\text { Radar logging of a } \\
\text { borehole }\end{array}$ & 620 & v & July 1979 & $\begin{array}{c}\text { Fridtjovbreen. } \\
\text { borehole } 2\end{array}$ & $\begin{array}{l}\text { Macheret, Vasilenko et al. } \\
\text { 1984: Kotlyakov \& } \\
\text { Macheret } 1987\end{array}$ \\
\hline $\begin{array}{l}\text { Wide-angle reflection } \\
\text { measurements }\end{array}$ & $2-13$ & $V$ & April 1988 & $\begin{array}{l}\text { Fridtjovbreen, near } \\
\text { borehole } 2\end{array}$ & $\begin{array}{l}\text { Glazovsky \& Moskalevsky } \\
\text { 1989; Glazovsky, } \\
\text { Konstantinova et al. 1991; } \\
\text { Glazovsky, Macheret et al. } \\
\text { 199l; Macheret, } \\
\text { Moskalevsky et al. } 1993\end{array}$ \\
\hline $\begin{array}{l}\text { Wide angle reflection } \\
\text { measurements }\end{array}$ & $2-13$ & V & April 1989 & Hansbreen, site $\mathrm{H} 5$ & $\begin{array}{l}\text { Glazovsky, Macheret et al. } \\
\text { 1991: Macheret, } \\
\text { Moskalevsky et al. } 1993\end{array}$ \\
\hline
\end{tabular}

Table 2. Average power reflection coefficient $R_{\mathrm{a}}$ from internal reflecting horizon in two-layered glaciers in northern Spitsbergen, calculated from airborne RES data collected along longitudinal profiles at $60 \mathrm{MHz}$ in May 1983 (Bamber 1989), and average water content $W_{\text {it }}^{\prime}$ in the upper part of temperate ice in these glaciers estimated by equations (2) and (6). The errors in water content estimations $\delta$ are given in assumption of $R_{\mathrm{a}}$ uncertainty $\pm 3 \mathrm{~dB}$. The average power reflection coefficients $R_{\mathrm{B}}$ from bedrock are also given. Both $R_{\mathrm{a}}$ and $R_{\mathrm{B}}$ are averages of corresponding power retlection coefficients calculated from individual wave forms recorded digitally along a flight line (Bamber 1989). Positions of glaciers are shown in Fig. 1.

\begin{tabular}{|c|c|c|c|c|c|c|}
\hline $\begin{array}{l}\text { Glacier no. as } \\
\text { given in Fig. } 1\end{array}$ & Glacier name & $R_{\mathrm{a}}, \mathrm{dB}$ & $W_{\mathrm{su}} \cdot g_{\mathrm{c}}$ & $+\delta$ & $-\delta$ & $R_{\mathrm{B}}, \mathrm{dB}$ \\
\hline 1 & Fimbulisen & -27.6 & 2.8 & 1.2 & -0.9 & $\mathrm{nd}^{*}$ \\
\hline 2 & Tunabreen & -27.1 & 2.9 & 1.3 & -0.9 & -15.9 \\
\hline 3 & Veteranen & -25.5 & 3.6 & 1.6 & -1.1 & -19.6 \\
\hline 4 & Sefströmbreen & -24.7 & 3.9 & 1.8 & -1.2 & -12.2 \\
\hline 5 & Mittag-Lefflerbreen & -24.7 & 3.9 & 1.8 & -1.2 & nd \\
\hline 6 & Nordenskiöldbreen & -24.4 & 4.1 & 1.8 & -1.3 & nd \\
\hline 7 & Chydeniusbreen & -24.1 & 4.3 & 1.9 & -1.3 & -19.0 \\
\hline 8 & Hochstetterbreen & -23.4 & 4.6 & 2.1 & $-1,4$ & -16.3 \\
\hline 9 & Formidablebreen & -23.3 & 4.7 & 2.1 & -1.4 & nd \\
\hline 10) & Wahlenbergbreen & -22.5 & 5.2 & 2.3 & -1.6 & -9.8 \\
\hline 11 & Uversbreen & -22.2 & 5.4 & 2.4 & -1.7 & -11.6 \\
\hline 12 & Vonbreen & -22.0 & 5.5 & 2.5 & -1.7 & -10.6 \\
\hline 13 & Aavatsmarkbreen & -21.4 & 5.9 & 2.7 & -1.8 & nd \\
\hline 14 & Abrahamsenbreen & -20.8 & 6.4 & 2.9 & -2.0 & -10.7 \\
\hline 15 & Eidembreen & -20.5 & 6.6 & 3.1 & -2.1 & -9.7 \\
\hline 16 & Fjortende Julibreen & -20.0 & 7.1 & 3.3 & -2.2 & -9.2 \\
\hline 17 & Borebreen & -19.8 & 7.2 & 3.4 & -2.3 & -7.7 \\
\hline 18 & Monacobreen & -19.1 & 7.9 & 3.7 & -2.5 & nd \\
\hline 19 & Kronebreen & -18.4 & 8.6 & 4.1 & -2.7 & -7.4 \\
\hline 20 & Kongsvegen & -18.0 & 9.1 & 4.3 & -2.9 & -9.1 \\
\hline \multirow[t]{2}{*}{21} & Nansenbreen & -18.0 & 9.1 & 4.3 & -2.9 & -8.0 \\
\hline & Mean value & & 5.7 & 2.6 & -1.8 & \\
\hline
\end{tabular}

\footnotetext{
*no data.
} 
(a)

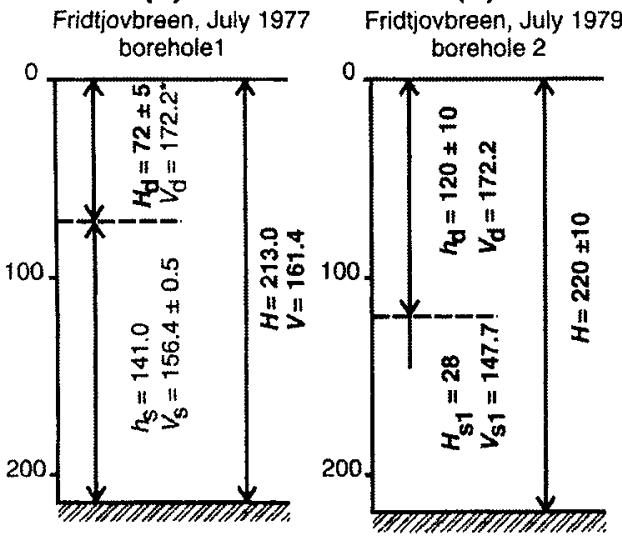

(c)

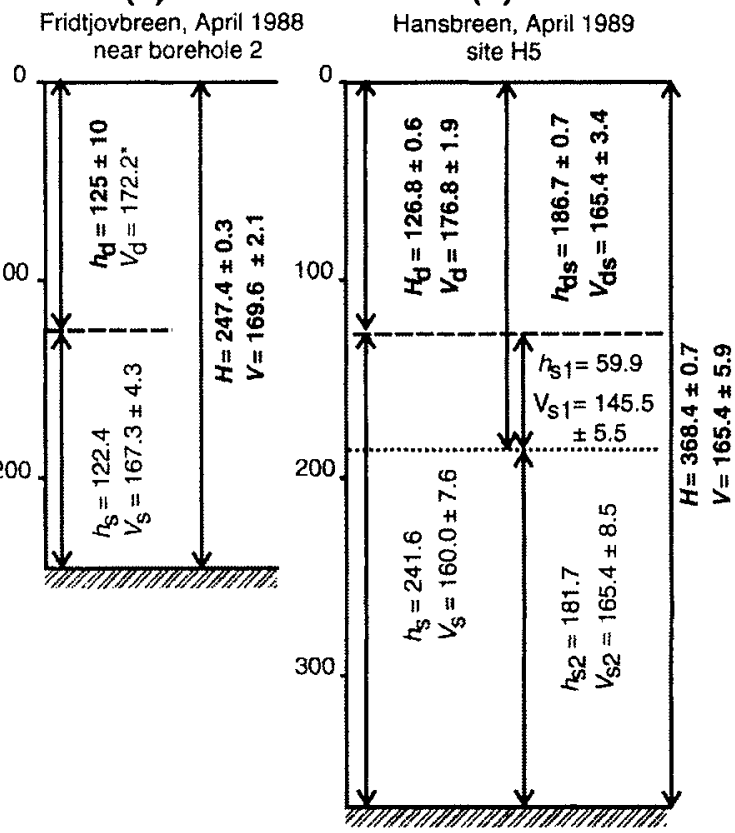

Fig. 4. Radio-wave velocities $\left(V, \mathrm{~m} \mathrm{\mu s}^{-1}\right)$ and ice thicknesses $(h, \mathrm{~m})$ of cold and temperate ice layers in Fridtjovbreen $(\mathrm{a}, \mathrm{b}, c)$ and Hansbreen (d). Estimations are based on: (a) RES data in the vicinity of borehole 1 (Macheret, Zhuralev et al. 1980); (b) radar logging of the borehole 2 (Macheret, Vasilenko et al. 1984; Kotlyakov \& Macheret 1987); (c, d) wide-angle reflection measurement data (Glazovsky \& Moskalevsky 1989: Glazovsky, Kolondra et al. 1991; Glazovsky, Konstantiniva et al. 1991; Glazovsky, Macheret et al. 1991; Macheret. Moskalevsky et al. 1993). Indexes used: $d$ is cold ice; $s$ is temperate ice; $s I$ and $s 2$ are upper and lower sections of temperate ice, and $d s$ is a sequence which includes cold ice and an upper layer of temperate ice. Measured and calculated velocities and ice thickness are indicated by bold and regular type, respectively. An asterisk indicates that the velocity values are taken from measurements in July 1979.

IRH along the same 21 glaciers are also presented by Bamber (1987a).

Results of measurements and calculations of thicknesses and RWVs for full depths in section of Fridtjovbreen and Hansbreen and for specific layers are given in Fig. 4. It is assumed that the velocity in the cold ice of Fridtjovbreen is constant and equals $172.2 \mathrm{~m} \mathrm{ss}^{-1}$ as measured by radar logging of borehole 2 .

\section{Absolute water content in temperate ice of two-layered Spitsbergen glaciers}

\section{Spatial variability}

In spring average water content $W_{\mathrm{au}}$ in the upper part of temperate ice, estimated by equations (2), (6) and (8) from average IRH power reflection coefficients $R_{\mathrm{a}}$ obtained on 21 two-layered glaciers of Spitsbergen (Bamber 1989), varies from glacier to glacier in the range $2.8-9.1 \%$ (Table 2). In all cases, even taking the error in $R$ estimation as $-3 \mathrm{~dB}$ that results in the $W_{\mathrm{au}}$ range $1.9-6.2 \%$, these values are higher than available values of water content (up to $1.4 \%$ ) measured directly in ice samples from temperate glaciers elsewhere in the world (Raymond \& Harrison 1975; Golubev 1976). They are also higher than values of $1.5-2 \%$ estimated from wide-angle reflection measurements of RWVs in temperate glacier ice of the Abramov glacier, Central Asia (Macheret, Moskalevsky et al. 1993; Frolov \& Macheret 1998). Suggesting that the $1.4 \%$ water content is the uppermost limit for the compact temperate ice, all excess of bulk water content above this limit in temperate glacier ice might concentrate in "macro inclusions", such as waterfilled cavities and veins. In this case, the "excess" average water content in "macro inclusions" of 

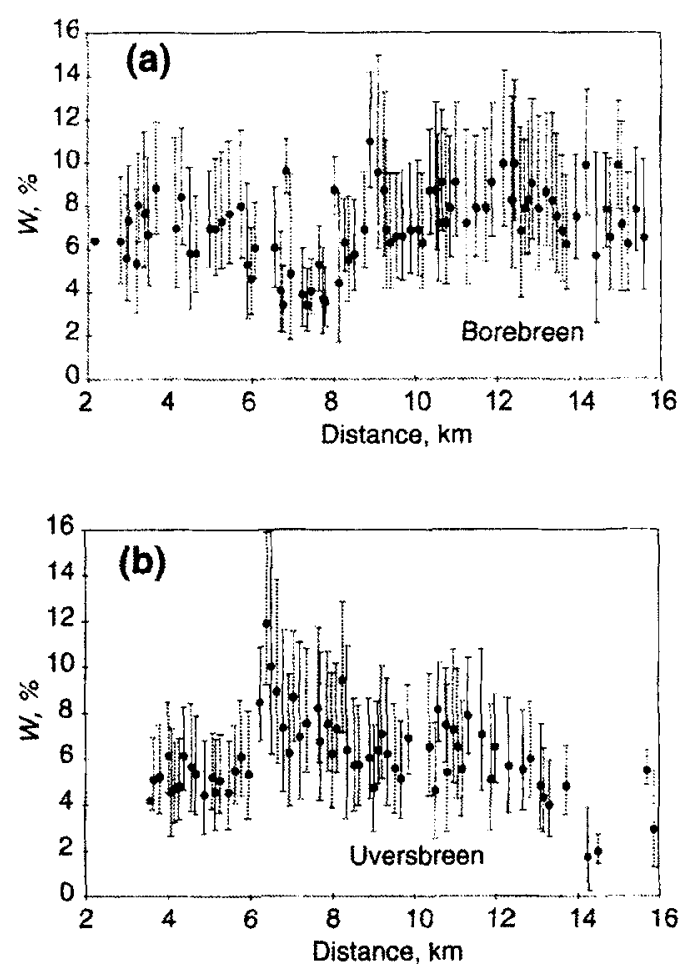

Fig. 5. Water content $W$ variations at the internal reflection horizon (IRH) along two glaciers on Spitsbergen: (a) Borebreen and (b) Uversbreen. $W$ values are calculated using equations (2) and (6), where power reflection coefficients $R$ from IRH along the glaciers are extracted from figures presented by Bamber (1987b. 1989) by means of digitizing. The error bars correspond to $R$ uncertainty of $\pm 3 \mathrm{~dB}$.

temperate ice in Spitsbergen glaciers (Table 2) is $1.4-7.7 \%$.

Within one glacier the water content $W_{\mathrm{u}}$ in the upper part of temperate ice, estimated from IRH reflection coefficients $R$ measured along RES profiles using individual wave forms (Bamber 1987a), varies over a rather wide range. For example, $W_{u}$ on Borebreen varies from 3.4 to $11.0 \%$, with peak frequency values $7.0 \%$ : on Uversbreen these values are $1.7-11.9 \%$ and $5.7 \%$. respectively (Fig. 5). Taking into account the error in $R$ measurement of $\pm 3 \mathrm{~dB}$, the variability of individual values of $W_{\mathrm{u}}$ within one glacier is comparable with variability of average values of $W_{\text {au }}$ for all the glaciers (Table 2, Fig. 5).

\section{Seasonal variations}

Average absolute water content $W$ in temperate ice as a whole, estimated by equations (6), (3) and (1) from RWV measurements (Fig. 4), is $2.4 \%$ in summer and $0.1 \%$ in spring on Fridtjovbreen, and $1.6 \%$ in spring on Hansbreen (Fig. 6), indicating the lower water content in spring than in summer. Therefore, even taking into account the uncertainty of $W$ estimation (see Figs. 2a, 6), seasonal variations of bulk water content in two-layered glaciers might reach $2.3 \%$. Assuming that the summer water content of $2.4 \%$ in Fridtjovbreen represents the total available volume that might be filled in different ratios by air and water in springtime (i.e. the total fractional water and air content $P$ in spring is $2.4 \%$ ), it is possible to reestimate the spring conditions using the equation (7) for a three-component system. In this case, water and air content is $0.7 \%$ and $1.7 \%$, respectively. Therefore, $70 \%$ of summer englacial water might drain from Fridtjovbreen before the spring comes.

\section{Variations with depth in temperate ice}

Water content $W$ in Fridtjovbreen and Hansbreen, estimated from RWV data (Figs. 6b, d), varies with depth in temperate ice. On Fridtjovbreen the upper $28 \mathrm{~m}$ of temperate ice contains $4.5 \%$ while the whole temperate sequence contains $2.4 \%$. On Hansbreen the upper $60 \mathrm{~m}$ of temperate ice contains $5.0 \%$ of water while the whole temperate sequence contains $1.6 \%$. Therefore in both cases the upper part of temperate ice is 2-3 times more water-saturated than the whole temperate layer. This phenomenon becomes even more evident in comparison to the water contents in the upper and lower parts of temperate ice. In Hansbreen the ratio of these values reaches 10:1 (Fig. 6d). High average water content in the upper temperate ice layer $\left(W_{\mathrm{au}}>3 \%\right)$ is also revealed for most glaciers by estimations based on IRH power reflection coefficients $R_{\mathrm{a}}$ (Table 2 ).

On the other hand, the RWV data from Fridtjovbreen indicate that more uniform water content distribution with depth is also possible in the temperate ice of two-layered glaciers (Figs. 6a, b). It corresponds with measurements of backscattered power from water inclusions in the temperate layer of Uversbreen, May 1991 (Hamran et al. 1996), which were interpreted as a gradual increase of relative water content only in the upper $10 \mathrm{~m}$ of temperate ice downward from the cold/temperate ice boundary, then with rather uniform distribution down to the bedrock. The 
Fig. 6. Average absolute water content $W(\%)$ in temperate ice in Fridtjovbreen $(a, b, c)$ and Hansbreen (d) from radio-wave velocity measurements shown in Fig. 5. Vertical lines show the average water content in the whole sequence of temperate ice and its specific layers. Horizontal error bars indicate uncertainty of $W$ estimation. (a)

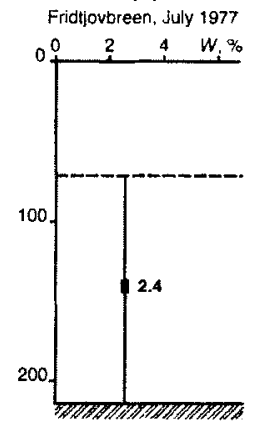

(b)

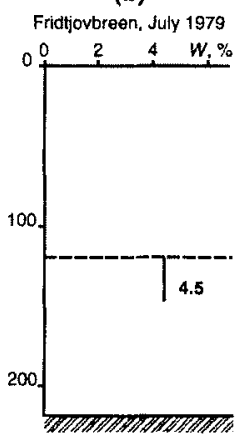

(c)

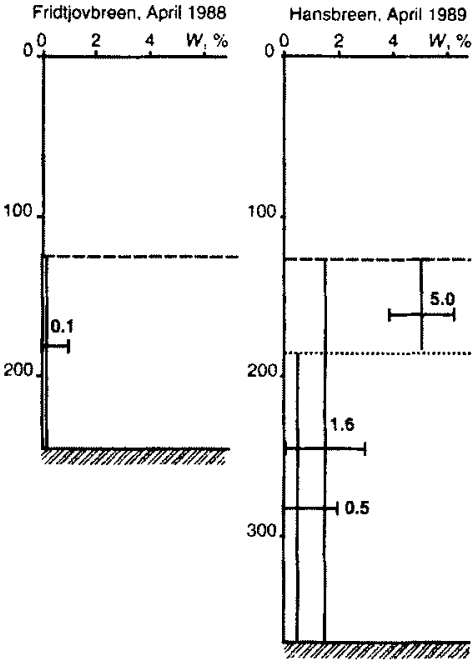

highest relative water content was found at glacier mouline sites, where water enters into the glacier during the melting season. Measurements of relative amplitudes of backscattered signals on Finsterwalderbreen (Fig. 1) show that the water inclusions occur throughout the temperate ice before the melting season, April 1994-95 (Ødegård et al. 1997).

\section{Discussion}

It is common knowledge (Golubev 1976) that water in glaciers appears from surficial melting, liquid precipitation, run-off from surrounding slopes and firn areas, groundwater as well as melting from dissipative heating and geothermal heat flux. Water gravitates down the glacier body because of infiltration through the snow/firn layer, and inflow throughout crevasses, channels, moulines and fracture zones, where it can be stored for a long time, if the ice temperature is close to the melting point, or drain out by a system of englacial channels. Therefore, water content and distribution should depend on the temperature regime, rate of surficial melting, type and pattern of ice facies zones, degree of ice discontinuity and development of internal drainage system, i.e. on a combination of complex glacioclimatic and dynamic factors with glacier internal structure. In particular, the permeability of the upper cold ice layer and temperate firn should determine the water influx to the temperate layer in polythermal glaciers. In this context the study of spatial and seasonal water changes in temperate ice of twolayered glaciers in relation with surficial melting rate is of considerable interest.

\section{Comparison of water content values derived from $P R C$ and RWV data}

Water content in the upper part of temperate ice estimated from average PRC data is somewhat higher than values derived from RWV data (Table 2, Fig. 6). Because no simultaneous measurements of both PRC and RWV are made on the same glacier, it is difficult to relate this difference with real variations, or estimation errors, or differences inherent in the methods themselves.

In particular, unexpectedly high values of water content in the upper part of temperate ice (Table 2) revealed from PRC data collected in the springtime might be attributed to the following limitations of plane-reflection boundary model described by equation (2).

The model is valid for cases in which the dimensions of water inclusions are much smaller than the radio-wavelength in ice, otherwise a more exact solution is necessary. Our estimations are based on data obtained at a frequency of $60 \mathrm{MHz}$ and, as shown by Bamber (1988), the threshold dimension of water inclusions for that frequency is $2.5 \mathrm{~cm}$. At this dimension the PRC values estimated from the plane model (equation 2) are equal to the PRCs derived from Mie's theory that applied for radio-wave scattering from the sphe- 
rical water bodies of arbitrary size in ice. But at larger water inclusions, much higher PRCs should be observed than the plane model predicts. The increase of water bodies' radius by only $2.5 \mathrm{~cm}$ above the threshold raises the PRC by $7 \mathrm{~dB}$ at the same water volume fraction in ice of $1 \%$. Thus our estimations might reflect the variations both in water content and/or in size of water macro inclusions. In this context, the appearance of water veins with cross-sections of $10-15 \mathrm{~mm}^{2}$ which occurred at depths more than $98 \mathrm{~m}$ in borehole 2 at Fridtjovbreen, i.e. at depths close to the IRH (Glazovsky, Krass et al. 1988) favours the hypothesis of PRC enhancement because of the macro inclusion effect.

On the other hand, the opposite effect might occur and superimpose on the water body influence. The model applied (equation 2) is valid when the boundary roughness is much smaller than the radio-wavelength in ice ( $2.8 \mathrm{~m}$ at a frequency of $60 \mathrm{MHz}$ ). In the case of a rough boundary, the power reflection coefficient $R$ reduces in range from 0 to $15 \mathrm{~dB}$ (Neal 1979), which leads to the underestimation of water content using equations (2), (6) and (8). Nevertheless, if the irregular IRH does occur, the water content assessments based on a flat boundary assumption might be used for the comparison of relative water content variations in different glaciers of the archipelago, suggesting a similar roughness parameter for IRH.

Both approaches used here for water content estimations have different sensitivities to the measurement errors (Figs. 2, 3). At higher water contents, the PRC method lacks precision, while the RWV method is rather stable and seems more reliable. Therefore, the RWV data - if available can contribute the calibrating ground for the PRC assessments.

All things considered, the PRC data provide a wide regional scope to understand the spatial hydrological pattern at IRH, but require further field and theoretical studies. Thus, our interpretation of PRC data given below, only in terms of water content variations, should be considered as the conventional simplification.

Spatial variability in absolute water content and surficial melting rate

Figure 1 and Table 2 show spatial variations of average water content $W_{\text {au }}$ in the upper part of temperate ice of two-layered glaciers, estimated from average power reflection coefficient $R_{\mathrm{a}}$. The surficial melting rate at the equilibrium line altitude (ELA) and predominant ice facies zones of northern Spitsbergen (Koryakin et al. 1985; Treshnikov 1985) are also shown. Figure I shows that the glaciers with lower average water content $\left(W_{\text {aul }}<5 \%\right)$ generally prevail in the north-eastern region, while glaciers with higher average water content $\left(W_{\mathrm{au}}>5 \%\right)$ are dominant in the northwestern region. These regions are also distinguished by different melting rates at the ELA less than $75 \mathrm{~g} \mathrm{~cm}^{-2}$ and more than $75 \mathrm{~g} \mathrm{~cm}^{-2}$, respectively. A more extended comparison of the melting contour line pattern with glacier distribution with different average water content $W_{\text {au }}$ reveals a rather close relationship: the higher the melting rate, the higher the water content. Exceptions to this rule are only Sefströmbreen and to some extent Wahlenbergbreen, where melting rates at ELA are as high as $125-150 \mathrm{~g} \mathrm{~cm}^{-2}$, but water content is only $3.9 \%$ and $5.2 \%$, respectively. In the north-western region the firn ice and warm firn ice facies zones prevail and favour meltwater inflow into glaciers, while predominance of firn ice and cold ice facies zones in the north-eastern region limits water influx. Therefore, the relationship between the surficial melting rate and glacier permeability with water content in the upper part of the temperate ice layer seems to be evident. Growth of individual PRCs at most accumulation areas seen from Bamber's data (1987a) supports the idea of a strong effect of water percolation on PRC values. Sefströmbreen and Wahlenbergbreen do not follow the rule, possibly as a result of a high ratio of superimposed ice, which protects the glaciers from water percolation.

Comparison of average water content $W_{\mathrm{au}}$ in the upper part of the temperate ice layer with average power reflection coefficients $R_{\mathrm{B}}$ from bedrock (Table 2) shows that $-19.6 \mathrm{~dB}<R_{\mathrm{B}}<-12.2 \mathrm{~dB}$ only when $W_{\mathrm{au}}<5 \%$, and in contrast $-7.4 \mathrm{~dB}>R_{\mathrm{B}}>-11.6 \mathrm{~dB}$ when $W_{\mathrm{au}}>5 \%$, i.e. the values correlate with each other. The relationship might be attributable to the more intensive water percolation in glaciers with higher water content, which is favourable for the presence of water film or water saturated sediments at the glacier bed. In both cases this increases $R_{\mathrm{B}}$ compared with dry bed conditions. However, PRCs from bedrock depend on many other factors, such as bedrock composition and roughness, water mineralization, water film thickness etc. (Bamber 1989). Therefore, the relationship of average water content $W_{\text {au }}$ in the upper temperate ice with $R_{\mathrm{B}}$ 
cannot explained as one-to-one correspondence with water influx to the bed.

\section{Seasonal variations in absolute water content and} surficial melting

According to RES data (Glazovsky \& Moskalevsky 1989; Glazovsky, Konstantinova et al. 1991; Glazovsky, Macheret et al. 1991), the ice volume of Fridtjovbreen is $7.6 \mathrm{~km}^{3}$, and the mean thickness of the upper cold ice layer is ca. $100 \mathrm{~m}$. Considering a glacier area of $48.7 \mathrm{~km}^{2}$, this corresponds to a temperate ice volume of $2.7 \mathrm{~km}^{3}$. The water content in temperate ice (as seen from Figs. 6a, c) increases by the end of the melting season by $2.3 \%$ or by $0.062 \mathrm{~km}^{3}$, which equals $1.28 \mathrm{~m}$ of water layer equivalent. On the other hand, the summer glacier mass balance in $1987 / 88$ was $1.49 \mathrm{~m}$ (Troitsky 1989), i.e. the melting volume was $0.073 \mathrm{~km}^{3}$. Therefore, assuming the values are representative, $85 \%$ of surface melting water migrates into the glacier, suggesting the essential contribution of summer melting in refilling the temperate ice layer. The same estimations, but with seasonal englacial water variations equal to $1.7 \%$ derived from the threecomponent equation (7), show that $63 \%$ of surficial melting might gravitate down to the temperate ice annually.

Some portion of percolated water refreezes at the base of the cold ice layer as follows from data of ice core drilling at site 2 on Fridtjovbreen (Macheret. Zagorodnov et al. 1985), where an ice layer $15 \mathrm{~m}$ thick with refrozen water channels was found. The refreezing rates of $0.2-0.6 \mathrm{~m} \mathrm{a}^{-1}$ were found from temperature measurements in boreholes on Finsterwalderbreen (Ødegård et al. 1997). Applying this value to Fridtjovbreen results in annual water refreezing ca. $0.0002-0.0007 \mathrm{~km}^{3}$, i.e. maximum losses for refreezing from total meltwater input are $1.5 \%$. Thus nearly $13.5-35.5 \%$ of meltwater drains from the glacier as a surficial run-off.

Water accumulated in the glacier body also drains out, as in springtime its volume is only $0.1-$ $0.7 \%$. The run-off distribution in the fall-winter period on Fridtjovbreen can be estimated indirectly by applying data of water run-off measurements conducted on Bertilbreen, Spitsbergen, which has a perennial run-off and temperate ice volume of $0.03 \mathrm{~km}^{3}$ (Gokhman \& Khodakov 1985). According to these data, the water run-off from the temperate ice is $0.00004 \mathrm{~km}^{3}$, or $40 \%$ of total glacier run-off during the cold period. Assuming that water run-off from the temperate ice is proportional to the temperate ice volume, the winter run-off from Fridtjovbreen is estimated as ca. $0.0036 \mathrm{~km}^{3}$. With all these assumptions the temperate ice of Fridtjovbreen drains $92-94 \%$ of water in the fall, and 6-8\% in wintertime. In turn, it indicates a well developed englacial water drainage system with a high rate of water filling in summertime, which is followed by rapid emptying.

In spring, the average water content in the temperate ice layer in Hansbreen is estimated as $1.6 \%$ (Fig. 6d). As the glacier volume is $10.47 \mathrm{~km}^{3}$, the temperate ice volume is $4.07 \mathrm{~km}^{3}$, and glacier area is $64 \mathrm{~km}^{2}$, so spring water storage in the glacier is estimated as $0.065 \mathrm{~km}^{3}$, or $1.02 \mathrm{~m}$ of water layer equivalent. In spring, the average water content in the temperate ice layer in Fridtjovbreen is $0.1-0.7 \%$, or $0.0027-0.0189 \mathrm{~km}^{3}$ (0.06- $-0.39 \mathrm{~m}$ of water layer equivalent). That is, the relative water content in Hansbreen is 2.6-17 times higher than in Fridtjovbreen in spring. Such a big difference can be assigned to the difference in glacier "voidness".

Additional support for this suggestion comes from data on cold ice. Average integral cold ice density, $\rho_{\mathrm{a}}$ estimated by equation (9) from RWV data (Fig. 4), is $0.870 \mathrm{Mg} \mathrm{m}^{-3}$ on Fridtjovbreen and $0.821 \mathrm{Mg} \mathrm{m}^{-3}$ on Hansbreen. Therefore, an average porosity of cold ice of Hansbreen, $p_{a}$ $(10.5 \%)$, is nearly 7.4 times higher than on Fridtjovbreen $(1.42 \%)$. The volume of air macro inclusions in the cold ice of Hansbreen, $\Delta \mathrm{p}$ estimated from equation (10) with $\rho_{0}=$ $0.904 \mathrm{Mg} \mathrm{m}^{-3}$, is also nearly 2.5 times higher than on Fridtjovbreen $(9.0 \%$ and $3.7 \%$, respectively).

Speleological studies on Hansbreen have revealed large cavities which consist of vertical shafts down to the depth of the cold/temperate ice boundary, connected to subhorizontal galleries below. Chambers are up to $10-15 \mathrm{~m}$ in diameter and in some cases have water pools of metre scale. In the cold/temperate ice transition zone at a depth exceeding $100 \mathrm{~m}$, "Swiss cheese"-type smalldiameter channels occur (Pulina \& Rehak 1991) along with the large channels.

\section{Conclusion}

Data on radio-wave velocities and power reflec- 
tion coefficients from the cold/temperate ice boundary in two-layered glaciers on Spitsbergen are highly promising for our understanding of the water content in polythermal glaciers in the Arctic. The PRC method is preferable in the assessment of spatial variations at IRH, but suffers from higher uncertainty in absolute water content estimations. The radio-wave velocity method reveals more stable results and allows to clarify the water distribution with depth, but is much more time and labour consumable.

The available data have been interpreted with certain assumptions concerning the radio-wave propagation and reflection models. The study shows that the mean water content $W_{\mathrm{au}}$ in the upper part of the temperate ice for 21 Spitsbergen glaciers is $5.7 \%$, varying from glacier to glacier in the range $2.8-9.1 \%$ before the melting season starts. In all cases the water content is higher than in the temperate glaciers. Within specific glaciers the water content $W_{u}$, in the upper part of temperate ice varies from 1.7 to $11.9 \%$, i.e. the water content variability along the RES crosssection for one glacier is comparable with variability of average values $W_{\text {au }}$ for 21 Spitsbergen glaciers. Seasonal water content changes in the temperate parts of two-layered glaciers can reach $2.3 \%$, ranging from $0.1 \%$ in spring to $2.4 \%$ in summer. Water content distribution with depth in some cases has a maximum at the upper part of the temperate ice $30-60 \mathrm{~m}$ thick and reaches $5 \%$ in the spring period, or it is uniform throughout the temperate ice sequence. Surficial melting rate at the ELA and glacier permeability are correlated rather well with average water content in the upper part of the temperate ice and bedrock power reflection coefficients. Water volume stored in the temperate ice of two-layered glaciers is enough to feed englacial water run-off during the whole cold period.

It should be noted that the complex nature of radio-wave propagation and reflection in polythermal glaciers requires further measurements of RWV and PRC performed repeatedly at cold and warm periods to understand the seasonal water variations with depth and at IRH. The solution of the problem of water macro inclusions needs further field studies and their theoretical interpretation.

Acknowledgements. - This work was supported by Russian Foundation of Basic Research Grants nos. 99-05-39094 and 99-
05-65551. Two anonymous referees gave thoughtful and helpful reviews that improved the manuscript.

\section{References}

Babenko. A. N. \& Macheret, Yu. Ya. 1996: O tochnosti opredeleniya parametrov dvukhsloynykh lednikov po dannym naklonnogo radiozondirovaniya. (Accuracy of parameters assessment for two-layered glaciers by wide-angle reflection measurements.) Materialy Glyatsioilogicheskikh Issledovaniy 80, 128-130.

Bamber, J. L. 1987a: Radio echo sounding studies of Svalbard glaciers. PhD thesis, Cambridge University.

Bamber, J. L. 1987b: Internal reflecting horizons in Spitsbergen glaciers. Ann. Glaciol. 9, 5-10.

Bamber. J. L. 1988: Enhanced radar scattering from water inclusions in ice. J. Glaciol. 34(/18), 293-296.

Bamber, J. L. 1989: Ice/bed interface and glacial properties of Svalbard ice masses deduced from airborne radio echosounding data. J. Glaciol. 35(1/9), 30-37.

Björnsson. H., Gjessing, Y., Hamran, S.-E., Hagen, J. O., Liestøl, O. \& Erlingsson, B. 1996: The thermal regime of subpolar glaciers mapped by multi-frequency radio-echo sounding. J. Glaciol. 42(140), 23-32.

Evans, S. 1965: Dielectric properties of ice and snow - a review. J. Glaciol. 5(42), 773-792.

Frolov. A. D. \& Macheret, Yu. Ya. 1998: Otsenka soderzhaniya vody $v$ subpolyarnykh i tyeplykh lednikakh po dannym izmereniy skorosti rasprostraneniya radiovoln. (Estimation of water content in subpolar and temperate glaciers by data of radio-wave velocity measurements.) Materialy Glvatsioilogicheskikh Issledovaniy 85, 148-154.

Fujita, S., Mae, S. \& Matsuoka, T. 1993: Dielectric anisotropy in ice $1 \mathrm{~h}$ at $9.7 \mathrm{GHz}$. Ann. Glaciol. 17, 276-280.

Glazovsky. A. F., Kolondra, L., Moskalevsky. M. Yu \& Jania, J. 1991: Issledovaniye prilivnogo lednika Khans na Shpitsbergene. (Study of tidewater Hansbreen glacier on Spitsbergen.) Materialy Glyatsioilogicheskikh Issledovaniy 71, 143-149.

Glazovsky. A. F., Konstantinova, T. N., Macheret, Yu. Ya \& Moskalevsky, M. Yu. 1991: Tolshchina l'da i podlyedny relief lednika Frit'iofa po dannym nazemnoy radiolokatsionnoy s" yemki. (Ice thickness, subglacial relief of Fridtjovbreen by data of ground-based radio-echo sounding survey. Materialy Glyatsioilogicheskikh Issledovaniy 72, 161-166.

Glazovsky, A. F., Krass, M. S. \& Macheret, Yu. Ya. 1998: Hydrothermal regime and dynamies of subpolar glaciers in changing climate. In P. Glowacki \& J. Bednarek (eds.); Polish Polar Studies: 25th International Polar Symposium the 100th anniversary of Prof. Henryk Arctowski's and Prof. Antoni Boleslaw Dobrowolski's participation in the Belgica expedition to the Antartic in 1887. Pp. 77-91. Warsaw: Institute of Geophysics, Polish Academy of Sciences.

Glazovsky. A. F.. Macheret, Yu. Ya., Moskalevsky, M. Yu. \& Jania. J. 1991: Tidewater glaciers of Spitsbergen. IAHS Publicutions 208, 229-239. International Assoc. of Hydrological Sciences.

Glazovsky, A. F. \& Moskalevsky, M. Yu.. 1989: Issledovaniya lednika Frit' iof na Shpitsbergene v 1988 godu. (Studies of Fridtjovbreen glacier on Spitsbergen in 1988.). Materialy Glyatsioilogicheskikh Issledovaniy 69, 148-153.

Gokhman, V. V. \& Khodakov, V. G. 1985; Gidrologiya lednikov i lednikovykh basseinov. (Hydrology of glaciers 
and glacier basins.) In V. M. Kotlyakov (ed.): Glyatsiologiva Shpitsbergena. (Glaciology of Spitsbergen.) Pp. 62-80. Moscow: Nauka Publ.

Golubev, G. N. 1976: Gidrologiya lednikov. (Hydrology of glaciers.) Leningrad: Gydrometeoizdat.

Gough, S. R. 1972: A low temperature dielectric cell and the permittivity of hexagonal ice to $2 \mathrm{~K}$. Can. J. Chem. $50(18)$, 3046-3051.

Hamran, S.-E., Aarholt, E., Hagen, J. O. \& Mo, P. 1996: Estimation of relative water content in sub-polar glacier using surface-penetration radar. J. Glaciol. 42(142), 533-537.

Koryakin, V. S., Krenke, A. N. \& Tareeva, A. M. 1985: Raschyetnaya akkumulyatsiya na vysote granitsy pitaniya. (Calculated accumulation at equilibrium line altitude.) In $\mathrm{V}$. M. Kotlyakov (ed.): Glyatsiologiva Shpitsbergena. (Glaciology of Spitsbergen.) Pp. 54-61. Moscow: Nauka Publ.

Kotlyakov, V. M. \& Macheret, Yu. Ya. 1987: Radio echosounding of subpolar glaciers in Svalbard: some problems and results of Soviet studies. Ann. Glaciol. 9, 151-159.

Looyenga, H. 1965: Dielectric constants of heterogeneous mixture. Physika 31(3), 401-406.

Macheret, Yu. Ya., Glazovsky, A. F., Krass, M. S., Bozhinsky, A. N.. Ignatieva. I. Yu., Konstantinova, T. N.. Larina, T. B. \& Moskalevsky, M. Yu. 1992: Stroyeniye, gidrotermicheskoye sostoyaniye i rezhim subpolyarnykh lednikov. (Structure, hydrothermal state and regime of subpolar glaciers.) In V. M. Kotlyakov (ed.): Rezhim i dinamika polvarnykh lednikovykh pokrovov. (Regime and dynamics of polar ice sheets.) Pp. 48115. St. Petersburg; Gidrometeoizdat.

Macheret, Yu. Ya., Moskalevsky, M. Yu., \& Vasilenko, E. V. 1993: Velocity of radio waves in glaciers as an indicator of their hydrothermal state, structure and regime. J. Glaciol. 39(1,32), 373-384.

Macheret, Yu. Ya., Vasilenko, E. V., Gromyko, A. N. \& Zhuravlev, A. B. 1984: Radiolokatsionny karotazh skvazhiny na lednike Frit'iof (Shpitsbergen). (Radar logging of a borehole on Fridtjovbreen, Spitsbergen.) Materialy Glyatsioilogicheskikh Issledovaniy 50, 198-203.

Macheret, Yu. Ya., Zagorodnov, V. S., Vasilenko, E. V., Gromyko, A. N. \& Zhuravlev, A. B. 1985: Issledovaniye prirody vnutrennikh radiolokatsionnykh otrazheniy na subpolyarnom lednike. (Study of the nature of internal radar reflection on a subpolar glacier.) Materialy Glyatsioilogicheskikh Issledovaniy' 54, 120-130.

Macheret. Yu. Ya. \& Zhuravlev, A. B. 1985: Tolshchina, ob"yem i stroyeniye lednikov. (Ice thickness, volume and structure of glaciers.) In V. M. Kotlyakov (ed.): Glyatsiologiya Shpitsbergrna. (Glaciology of Spitsibergen.) Pp. 7-35. Moscow: Nauka Publ.

Macheret, Yu. Ya. Zhuravlev, A. B. \& Gromyko, A. N. 1980: Radiolokatsionnyye issledovaniya lednikov Shpitsbergena $v$ 1977 g. (Radio-echo sounding investigations of glaciers on Spitsbergen in 1977.) Materialy Glyatsioilogicheskikh Issledovaniy 38. 279-286.

Mätzler, C. \& Wegmüller, U. 1987: Dielectric properties of fresh-water ice at microwave frequencies. J. Phys. (D) Appl. Phys. 20, 1623-1630.

Moore, J. C., Pälli, A., Ludwig, F.. Blatter, H., Jania, J., Gadek. B., Glowacki, P.. Mochnacki, D. \& Isaksson, E. 1999: High resolution hydrothermal structure of Hansbreen. Spitsbergen, mapped by ground penetrating radar. J. Glaciol. 45(151), $524-532$.

Neal, C. S. 1979: The dynamics of the Ross Ice Shelf revealed by radio echo-sounding. J. Glaciol. 24(90), 295-307.

Ødegărd, R. S., Hagen, J. O. \& Hamran, S.-E. 1997: Comparison of radio-echo sounding $(30-1000 \mathrm{MHz})$ and high-resolution borehole-temperature measurements at Finsterwalderbreen. southern Spitsbergen, Svalbard. Ann. Glaciol. 24, 262-267.

Pulina, M. \& Rehak, J. 1991: Glacier caves in Spitsbergen. In A. Eraso (ed.): Ist International Symposium on Glacier Caves and Karst in Polar Regions. Proceedings, acts. Pp. 93-117. Madrid: International Working Group on Glacier Caves and Karst in Polar Regions.

Raymond, C. F. \& Harrison, W. D. 1975: Some observations on the behaviour of liquid and gas phases in temperate glacier ice. J. Glaciol. 14(71), 213-232.

Sihvola, A., Nyfors, E. \& Tiuri, M. 1985: Mixing formulae and experimental results for the dielectric constant of snow. $J$. Glaciol. 31(108), 163-170.

Smith, B. M. E. \& Evans, S. 1972: Radio echo sounding: absorption and scattering by water inclusion and ice lenses. $J$. Glaciol. 11(61), 133-146.

Treshnikov, A. F. (ed.) 1985: Atlas Arktiki. (Atlas of the Arctic.) Vol, 1. Leningrad: General Board of Geodesy and Cartography of the USSR.

Troitsky, L. S. 1989: Balans massy lednikov Shpitsbergena v 1985/86, 1986/87 i $1987 / 88$ balansovykh godakh. (Mass balance of Spitsbergen glaciers in 1985/86, 1986/87 and $1987 / 88$ balance years.) Materialy Glyatsioilogicheskikh Issledovaniy 67, 194-196. 